\title{
Indirectivity and resultativity in Tundra Nenets
}

This article deals with indirective and resultative predicates in Tundra Nenets. The focus is on two different categories of verbal inflection marked with the suffix -we, the resultative past participle and the narrative mood. The article discusses the functions, syntactic properties and common origin of these two predicate structures. It will be argued that the narrative mood developed from the past participle predicate in an earlier stage of the Nenets languages through reanalysis of the resultative predicate as a perfect/evidential form and transition of the non-finite predicate into a finite conjugation.
1. Introduction
2. The narrative mood and indirective evidentiality
3. The past participle and orientation
4. The resultative predicate $-w e$
5. The derivational resultative $-b e j$
6. Development of the resultative and perfect/ evidential constructions
7. Conclusion

\section{Introduction}

In Tundra Nenets, the suffix $-w e^{1}$ is used in two different functions and to mark two different categories of verbal inflection. First, it is the suffix of past participle and second, in finite conjugation, the suffix is used to denote evidentially marked past events. The past participle occurs commonly as a modifier of a noun (1). In addition to this, the past participle appears in predicative position in resultative or impersonal passive constructions, as in (2):

(1) xoba-xad sced-wī píwa-?

fur-ABL sew-PTCP.PST boot-PL

'boots sewn of leather' (of-leather sewn boots) (NW: 21.9.2006)

(2) Đopoj śanaku toxoća-xad sced-wì one toy patch-ABL sew-PTCP.PST.3SG

'one toy is sewn of patches' (one toy (is) of-patch sewn) (NW: 19.7.2008) 
The participle soedwi 'sewn' in example 1, modifying the head noun 'boots', appears in attributive position, which is typical of participles in general, as they are characterized as verbal adjectives (see Koptjevskaja-Tamm 1993: 42; Haspelmath 1994: 152). In predicative position, in Tundra Nenets participles ( $s a d w \bar{\imath}$ 'is sewn' in 2), as well as verbs and nouns in indicative affirmative clauses, may act as predicates of a clause with no copula.

The suffix used in the finite conjugation has been earlier referred to as perfect (e.g. Labanauskas 1974), narrative (e. g. Collinder 1957: 441; Salminen 1997: 98 ) and inferential (Nikolaeva 2014: 93-96). In this paper, I will use the term narrative mood based on the categorical status of the suffix, which morphologically belongs to the mood paradigm in Tundra Nenets (Salminen 1997: 98). In finite conjugation, the narrative mood -we most commonly denotes indirect information source of a past event, reported or inferred information or distance between the speaker and the stated action or event (3).

(3) jilée-wa-n-ta jampo-nh mol'a yoka pani-m? soed $-w \bar{\imath}$ live-NMLZ-GEN-3SG.POss long-LAT already many clothing-ACC sew-NARR.3SG 'During her lifetime she has sewn many clothes. (NW: 20.3.2008)

As can be noted in examples 2 and 3, when affixed to the predicate verb, the suffix -we can be either the past participle in a nominal predicate (2), or the narrative mood in a finite verbal predicate (3), both referring to a past event or action and its results or current relevance. Due to the identical form of the past participle and narrative mood suffixes and their similar function in predicative position, the narrative mood has not been distinguished as a separate category in many descriptions of the language.

For example, Tereščenko (1947: 182, 190; 1965: 902, 905; 1973: 144), Kuprijanova et al. (1985), Décsy (1966: 59-60), and Hajdú (1968: 51, 65) treat the predicate forms in -we as special forms of the past participle with personal inflection. This has led to misinterpretations repeated in typological studies, such as Aikhenvald (2004: 118) doing her best to interpret the references (Tereščenko 1973; Perrot 1996) and suggesting that the past participle is used in Nenets folklore as narrative technique. This is a misunderstanding, as a distinctive finite evidential marker can be distinguished both syntactically and semantically from the past participle predicate. Labanauskas (1974: 46-47) points out that the narrative mood (perfect in Labanauskas' terminology) combines with all three conjugation types of Tundra Nenets: it takes the personal suffixes of the subjective, objective 
and reflexive conjugation. Based on the morphology and function of the finite -we form, Labanauskas defines it a mood marker that has developed from the past participle. The same conclusion is supported in the modern grammar of Tundra Nenets (Nikolaeva 2014: 93).

Most of the earlier studies refer to some kind of connection between the past participle and the narrative, either by analysing them as one and the same form with different uses (Castrén 1845; Tereščenko 1947: 182, 190; 1973: 144), or by referring to the origin of the narrative mood in the past participle (Labanauskas 1974: 47, Nikolaeva 2014: 93; see also Salminen 1997: 109). Nonetheless, the distribution of the two forms in predicate constructions and the mechanisms behind the assumed grammaticalization have not gained attention thus far. This is what the present study aims to contribute to the discussion. In this study, I will investigate the differences and similarities between the narrative mood and the past participle predicate. Moreover, I will discuss the preconditions for and processes of the possible grammaticalization of the participle into the narrative mood marker. In this study, I will give special consideration to the semantics and syntax of the structures from the perspective of similar grammaticalization processes known from other languages.

The study is organized in the following way: Section 2 gives an overview of the functions of the narrative mood in Tundra Nenets. Sections 3-5 analyse the syntax and semantics of the past participles and the related suffix - bej, particularly in predicate position, where their main function is to denote resultativity. In section 6 , I will argue that the history of the two homonymous morphemes is intertwined and that it reflects the tendency of resultatives to develop into perfects and indirectives, which is attested in languages areally and structurally close to Tundra Nenets. Finally, section 7 draws conclusions based on the findings.

The data consists of selected texts and recordings of spoken language. The texts consulted include Nenets folklore stories (JamLa) and newspaper articles in Tundra Nenets (the column Ялумд” from the years 2005-2012, appearing in Нярбяна вындер (= NW), the local newspaper of the Nenets Autonomous Okrug) as well as the sample sentences in Tereščenko 1965 (T65). The spoken data consist of fieldwork materials from the Taimyr Peninsula (NenTay 2011), including spontaneous stories as well as elicited translation sentences that were recorded in autumn 2011. ${ }^{3}$ In addition to these, I will refer to previous studies on the topic (Labanauskas 1974; Salminen 1997: 97; Tereščenko 1947; 1973; Ljublinskaja \& Malčukov 2007: 
456-462). I will give the examples in a transcription based on the Nenets orthography transliterated into the Finno-Ugric transcription (FUT). However, I have made some modifications to the orthography in order to present the most essential morphological oppositions ${ }^{4}$.

\section{The narrative mood and indirective evidentiality}

In all types of data used in this study, the narrative mood is the most frequently used non-indicative mood marker. The narrative mood is mutually exclusive with any other mood markers. However, it co-occurs with tense markers, the future and the general past (preterite), as well as the habitual aspect. Combined with the future tense, it denotes past intention or necessity (Nikolaeva 2014: 93), and combined with the preterite marker, it encodes more remote past (Ljublinskaja \& Malčukov 2007: 459-461). Most commonly, however, the narrative mood appears with no additional tense marking, denoting a past action or event. Consider the following examples, which represent the three finite conjugation types of Tundra Nenets, the subjective (4), objective (5), and the reflexive (6).
(4) pida xībāâwa-m pí-xəna məne-mī she someone-ACC outside.LOC see-NARR.3SG

'She saw/has seen someone outside.' (NenTay2011_TMP)

(5) tiki śer-m jī-sawej-h śerta-we-da

this thing-ACC smart-COMIT-GEN make-NARR.SG<3SG

'He has done this smartly'. (T65: 150)

(6) $j i^{2} \quad x u l c a-w \bar{l}^{2}$

water get.muddy-NARR.3SG.REFL

'The water has become muddy.' (T65: 779)

When referring to past events and actions, the narrative mood marker is often used to create certain distance between the speaker and the stated event or action. This usually means that the speaker is retelling something that she has not witnessed herself and has heard or learned from an unknown source, or source that is not necessary to be mentioned. It may also be something that the speaker infers from traces, results or consequences that she has access into, or a past event that the speaker tells in order to give background or relevance for something on discussion. This is why it is often used when telling something about other people (example (7)), something that the speaker has not witnessed and that cannot be considered as 
a generally known fact, but rather something that the speaker has learned from other sources or something that she infers from visual evidence (example 8).

(7) škola-xəna toxolko-wa-n-ta malíkjana sawa-wna padtayko-wi school-LOC study-NMLZ-GEN-3SG.POSs during good-Pros draw-NARR.3SG 'At the time when he studied at school, he was good at painting.' (NW: 16.2.2006)

(8) Etno-kulturnij

ethno-cultural noka xībaríi-? many person-PL xadako-? grandmother-PL

\section{ćentr-xəna} centre-LOC $m \partial^{\prime} l e-j d \partial-\dot{c}$;

noni-? ${ }^{2}$ píribta-? to-wi-?

boy-PL girl-PL come-NARR-3PL

'Many people gathered in the ethno-cultural centre in order to partake in the Crow's day celebration. Old women, small children, young women, boys and girls had come there.' (NW: 24.4.2008)

In example (8), the narrative mood (tow $\bar{\imath}^{2}$ 'had come') is contrasted with the general past tense, the preterite (mo'lejdoć 'gathered'). The first part, reporting that many people gathered to celebrate the Crow's day, is told in the preterite tense and the focus is on the action. The second part, telling that different kinds of people had come to the celebration, is told in the narrative mood, and the focus is on the relevance of a prior action, an action that has results that hold at the reference point (the people came $\rightarrow$ they were present).

In earlier studies, the narrative mood has been labelled as perfect (Labanauskas 1974; Ljublinskaja \& Malčukov 2007: 456-459). Perfect (in some studies labelled anterior) has usually been defined as past action with current relevance (Dahl 1985; Nedjalkov \& Jaxontov 1988: 15; Bybee et al. 1994: 54, 61). According to the definition given by Dahl \& Velupillai (2013) in The World Atlas of Language Structures (WALS), the perfect has at least two related but distinguishable uses: resultative use ("of an event, which has results that hold at the time of speech") and experiential use ("i. e. to say that a certain type of event took place one or more times over an interval of time ---: I have seen worse things in my life."). The resultative use of the perfect illustrates well the function of the narrative mood form in example 8 above, and in many respects, the definition of perfect corresponds to the functions of the narrative mood. However, the 
definition of perfect does not cover the evidential meaning, the indirect or distanced status of the information, which will be illustrated in the following examples.

In addition to reporting events about other people and events that the speaker has not witnessed herself, the narrative mood can also be used with the first person, telling about actions and events that the speaker has experienced and taken part in herself. Also in these cases, the narrative mood denotes some kind of distance between the speaker and the past event. It can be used when telling about events and experiences that the speaker does not remember well or events that have taken place without the speaker's control or active involvement, consider 9:

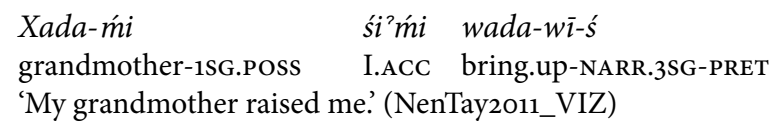

A special instance of retelling past events that the speaker has not witnessed herself is telling narratives and folktales. The name of the mood narrative, relatively widely used in the studies of Samoyedic languages, is easily associated with certain genres of language use. However, tales in Tundra Nenets are usually not told in the narrative mood, and the events in narratives are commonly told in present tense of the indicative, sometimes also in the general past tense. Nevertheless, the narrative mood is also used, and it appears to be a conventionalized habit to begin a narrative using the narrative mood. Of the 44 narratives in the Nenets folklore text collection JamLa, 40 start with a couple of sentences told in the narrative mood. The beginning part of the folklore texts, told using the narrative mood, usually presents the main characters and the environment of the story before going into the actual events of the storyline, which are typically told in present tense. Consider examples 10 and 11, which represent the opening sentences of narratives:

(10) Nardalo xada-n-ta ńa

Ngardalyo grand.mother-GEN-3SG.POss with

śid'a-mpoj-ye

jile-we-xeh

tWo-MODER-ESSTR live-NARR-3DU

'Ngardalyo lived alone with her grandmother (the two of them)' (JamLa: 61) 

(11) Nawnanta xunananta ji[b]ća yabćena jaw-h war-xəna once sometime salty smelling sea-GEN shore-LOC yobh ḿadî-koća təńa-wī. one tent-DIM exist-NARR.3SG
T'iki ḿadí-koća-xəna ńe jilé-wì. this tent-DIM-LOC woman live-NARR.3SG
Num-ta Tab Ed Xewko yoe-wī. name-3SG.Poss Tab Ed Xewko be-NARR.3SG Woesako-da junku-wī. Weńe-koća-nta husband-3SG.POss not.exists-NARR.3SG dog-DIM-GEN.3SG.POss ńa jala-ntih śidá-mpoj-ne jile-we-xeh with day-GEN.2DU.POSS two-DER-ESSTR live-NARR-3DU 'Once upon a time on a salty seashore, there was a small tent. In the tent there lived a woman. Her name was Tab Ed Xewko. She had no husband. She lived all their days with her dog, just the two of them. (JamLa: 41)

After the introduction part where the prevailing conditions are described using the narrative mood, the actual storyline of the narrative is told in present tense and in the indicative mood. The narrative illustrated in example 11, from the beginning of the tale, continues as demonstrated in 12:

(12) Nobykuna
one.time

Tab Ed Xewko

Tab Ed Xewko

ja-[h] sid'a

land-GEN two xūbta-xəna weńe-koća-da morning-LOC wene-koca-da tóre- $j^{2}$

bark-REFL.3SG

'One time the dog started barking in the morning. Tab Ed Xewko went out of the tent and looked to both sides.' (JamLa: 41)

It can be noted that in the tale illustrated in examples 11 and 12, the narrative mood is used to indicate the theme and general setting of the tale, including the main characters and the circumstances they live in, and when the actual events are told, the indicative present or past tense is used.

The preterite form of the narrative mood (also the pluperfect) is described as denoting a more remote temporal distance between the time of speech and the topic time (Ljublinskaja \& Malčukov 2007: 459-461). In the data used in this study, the preterite of the narrative mood is not very frequently used in folklore texts (JamLa), and there are fewer than twenty examples in $\mathrm{T} 65^{5}$. However, in the newspaper texts (NW), which represent the western variety of Tundra Nenets, the preterite of the narrative mood 
is the most common strategy used to encode past tense and more commonly used than plain narrative mood or plain preterite. Whereas JamLa, which represents the eastern varieties, contains only a couple of examples of the narrative preterite, and the narrative mood with no preterite marking is more frequent than the general past (indicative preterite), NW has many more examples of the narrative preterite than the indicative preterite, and the narrative mood with no preterite marking is relatively rarely used. ${ }^{6}$ Most newspaper texts are written in the present tense, as they give information on current news. However, reference to past tense is needed in the texts when they provide the background information and history of the people and events that are the topic of the news. A typical text in newspapers is a biography of a currently interesting person, written mostly in the narrative preterite. Consider example 13:

$\begin{array}{lllll}\text { (13) Leonid Aleksejevič } & \text { Jamal-[h] } & \text { ńana } & 1955 & \text { po-xəna } \\ \text { Leonid Alekseyevič } & \text { Jamal-GEN } & \text { POSTP.LOC } 1955 & \text { year-LOC } \\ \text { maj' jiŕi-xana } & \text { soja-wi-ś } & & \\ \text { May month-Loc } & \text { be.born-NARR.3SG-PRET } & \\ \text { 'Leonid Alekseyevič was born in May 1955'. (NW: 16.2.2006) }\end{array}$

It is possible that the fact that newspaper articles represent a different genre of text than folklore narratives could explain the difference in the frequency of the preterite of the narrative mood. It seems more likely, however, that the explanation can be found in dialectal variation. The texts in NW represent the western variety of Tundra Nenets and might therefore differ from other varieties. Comparison to newspaper texts published in Taimyr in the easternmost area where Tundra Nenets is spoken supports this hypothesis. It seems that in the texts published in Taimyr, the frequency of the preterite of the narrative mood is as low as in the folklore narratives.

Furthermore, in addition to the high frequency of the preterite forms of the narrative mood, another special characteristic of the newspaper texts from the western area is that deverbal adjectival resultative forms in - bej are relatively frequently used as predicates. In the texts, there are examples of the forms in -bej used in the function of the resultative perfect, as demonstrated in 14 (see also Nikolaeva 2014: 108). The forms in -bej will be further discussed in section 5 . 


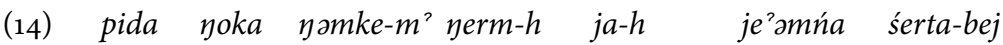
(s)he much thing-ACC north-GEN land-GEN for do-RES.3SG 'She has done a lot for the Northern land.' (NW: 15.11.2005)

Another function of the narrative mood, in addition to encoding perfect and non-witnessed past, has been described with the concept of mirativity (Ljublinskaja \& Malčukov 2007: 456-459; Nikolaeva 2014: 95). Usually the narrative mood is used in clauses where there is temporal distance between the time of speech and the topic time, as demonstrated in the previous examples. However, the narrative mood can also refer to current situations. Consider examples 15 and 16:

(15) $x i j$

tuko-xana me-we-n!

EXCLAM this-LOC be-NARR-2SG

'Hey, you appeared to be here!' (T65: 790)

Introduction for 16: [An old man and a giant decide to compete about which one of them owns the sun. The old man wins the game with his cleverness.]

\begin{tabular}{|c|c|c|c|c|}
\hline (16) & $\begin{array}{l}\text { tarća } \\
\text { this }\end{array}$ & $\begin{array}{l}\text { yadim-ć } \\
\text { turn.up-CNV }\end{array}$ & $\begin{array}{l}\text { śodba-ja } \\
\text { giant-AUG }\end{array}$ & $\begin{array}{l}m a: \\
\text { say.3sG }\end{array}$ \\
\hline & məń & xajer-ḿmi & & \\
\hline & I & sun-1SG.POSs & ist-NARR.3SG & \\
\hline
\end{tabular}

In both examples above, the speaker discovers the current state of affairs, which is new information or even surprising to her/him. Encoding new information or immediate perception of events (Lazard 2001: 361), in addition to the speaker's surprise or unpreparedness for the observed situation (DeLancey 1997: 36) as well as sudden discovery and counter-expectation (Aikhenvald 2012: 437, 473), are the meanings usually connected to the concept of mirativity. Mirativity, as defined by DeLancey (1997), has been questioned both as a cross-linguistic function and as an independent language-internal category (Hill 2012). However, contrary to this, it has been convincingly argued that in many languages, unexpectedness or new information is one of the central usages of those categories that encode indirect evidentiality (Slobin \& Aksu 1982: 197-198; Aikhenvald 2004: 195-215; Lazard 1999). In these languages, a perfect or indirective, 
like the narrative mood in Tundra Nenets, expresses different types of non-first-hand information, as well as different aspects of mirativity.

An indirect evidential form that encodes such functions as hearsay, inference and mirative, something similar to the Tundra Nenets narrative, is a characteristic of several languages of the Central Eurasian area (Lazard 2001: 361-363; Comrie 2000; see also "pan-Eurasian evidential perfect" in Nichols 1986: 253). Lazard (1999) refers to these categories as mediative, while Johanson (2000) and Lindstedt (2000: 375) have suggested the term indirective. In addition to Turkish and Balkan Slavic languages, the area of these indirect evidentials appears to extend from the Turkic languages to many of their neighbouring languages (Johanson 2000: 83-84; Aikhenvald 2004: 289) covering all Turkic languages (Johanson 2000: 61) as well as for example Armenian and Albanian (Slobin \& Aksu 1982: 197-198; Friedman 2003; Lazard 2001: 361-363). They can also be found in Eastern Uralic languages such as Khanty, the Permic languages and Mari, as well as Tungusic languages (Nikolaeva 1999; Leinonen 2000: 421-422; Malchukov 2000). The semantics of these indirect evidentials vary from one language to another, but their functions can typically be described with the concepts of hearsay, inference and mirative, similar concepts that have been used to describe the various functions of the narrative mood in Tundra Nenets ${ }^{8}$ (Labanauskas 1974; Ljublinskaja \& Malčukov 2007: 456-459).

The narrative mood in Tundra Nenets is used for encoding indirect information and backgrounding the narratives as well as for expressing mirativity, but it also denotes past action with current relevance, which is the primary definition of perfect. In fact, there is a cross-linguistically documented tendency for perfects to develop into indirect evidentials (Bybee et al. 1994: 95; Lindstedt 2000: 371-374). Aikhenvald (2004: 112) explains the semantic connection of non-first-hand information and perfect with the main function of perfect and its focus on the results of a past event. Traces or results of a past action or event are the basis for drawing the inference on the actual past event. However, inference based on traces of a past event requires observation of the results as they appear in the current moment (see also Dahl 1985). A more fine-grained analysis of the interconnection of this development and the relation of perfect and indirective meaning to resultatives will be given in section 4 .

Despite the fact that the narrative mood conveys a wide range of information sources and meanings related to evidentiality, it is only one of the 
many non-first-hand evidential markers in the language. Morphosyntactically speaking, the finite suffix in -we belongs to the mood category of the language (Salminen 1997: 98). The mood category consists of 17 different suffixes used in expressing different person and temporal reference of altogether 13 evidential, epistemic, deontic functions as well as clause type. Members of the mood category can combine with all conjugations, the subjective, objective and reflexive, they apply verbal negation affixing to the negative verb instead of the non-finite connegative form of the main verb, and they are mutually exclusive, so that in one verb form there can be only one mood marker (Salminen 1997: 97).

In addition to the narrative mood, the category includes several other suffixes that express different types of non-first-hand evidentiality. These are modal-evidential suffixes such as inferentials in -nake/-weke encoding inference and reasoning, and similative-evidentials in -naraxa, -wantaraxa, -raxawe denoting information inferred on basis of visual observation, similar to English 'seemingly' (see also Labanauskas 1981, 1982; Kuznecova \& Usenkova 2006; Ljublinskaja \& Malčukov 2007: 448-452). Two of these mood markers, namely -weke and -raxawe, consist of compound suffixes, where the element -we is apparently originally the same element as in the narrative mood. In these compound suffixes, too, the marker -we denotes past tense, while the other part denotes the evidential meaning (Labanauskas 1981, 1982; Jalava 2012). Consider example 17:

(17) pida $\quad$ yomkewa-m $m$ temta-weki
he something-ACC buy-PROB.PST.3SG
'She probably bought something.' (NenTay2011_TMP)

These mood markers have variants for other tenses, the present and the future, where they apply different temporal elements (-na for present, -wonta for future) compounded with the evidential-marking part of the suffix. In addition to the indirect evidential suffixes, there is one direct evidential suffix in Tundra Nenets, the auditive, which is used to encode direct nonvisual perception but sometimes also reported information.

In the modal-evidential system of Tundra Nenets represented by the mood category, the narrative mood has its place as an indirect evidential. In some contexts, its function is close to other mood suffixes that denote different shades of non-first-hand evidentiality, but unlike many other non-first-hand suffixes, the narrative mood usually does not denote epistemic evaluation, but instead emphasizes the indirectness of the informa- 
tion source or distance between the told events and the moment of speech. Categories with similar functions appear in many languages of the socalled Central Eurasian area. These categories (indirectives, mediatives, etc.) are typically linked to small evidentiality systems such as "non-firsthand versus everything else" (Aikhenvald 2004: 29-31). In Tundra Nenets, however, the narrative mood is included in a rich system of grammatical modal-evidential suffixes.

\section{The past participle and orientation}

The past participle in $-w e(\sim-w \bar{\imath} \sim-m e \sim-m \bar{\imath})$, e. g. mancara- $w \bar{\imath}$ ' the one who worked', is one of the four participles in Tundra Nenets. The others are the present (aorist) participle with the suffix -na (e.g. moncara-na 'working'), the future participle with the suffix -wanta (e.g. mancara-wanta 'the one who will/must work'), and the negative participle with the suffix -watawej (e. g. moncara-watawej).

The past participle can be either active or passive with relation to its head, depending on the transitivity of the verb. With intransitive verbs, the past participle is oriented towards the verb's agent participant, as in 18 , and the reading is active:

$$
\begin{aligned}
& \text { wìn-kad to-wī } \quad \text { yáekī } \\
& \text { tundra-ABL come-PTCP.PST child } \\
& \text { 'the child who has come from the tundra' (T65: 846) }
\end{aligned}
$$

As for transitive verbs, when affixed to these, the past participle is oriented towards the verb's patient participant, and it has passive meaning. Consider example 19 (= 1 in section 1$)$ :

$$
\begin{array}{lll}
\text { xoba-xad } & \text { sced-wi } & \text { píwa-? } \\
\text { fur-ABL } & \text { sew-PTCP.PST } & \text { boot-PL } \\
\text { 'boots sewn of leather' (of-leather sewn boots) (NW: 21.9.2006) }
\end{array}
$$

In some languages, there are different participial markers for active and passive participles. For example, in Finnish, the participle -NUT is always oriented towards the verb's agent: tul-lut 'the one who came' and the participle -TU is oriented towards the verb's direct object: ommel-tu '(the item that was) sewn'. In a language such as Tundra Nenets, where the same participial suffix is used for active and passive interpretation, the notion of orientation (see Haspelmath 1994: 152-154, adopted from Lehmann 1984: 152) 
describes the active-passive distinction. Table 1 below illustrates the past participles and their orientation in Tundra Nenets and Finnish. In Tundra Nenets, there is only one past participle that can be oriented either towards the agent or the patient, depending on transitivity of the verb. In Finnish, past participles are inherently oriented so that the marker specifies the orientation.

\begin{tabular}{|l|l|l|l|}
\cline { 2 - 3 } \multicolumn{1}{c|}{} & Tundra Nenets & Finnish & \multicolumn{1}{c}{} \\
\hline Agent-oriented & towi $(\mathrm{WE})$ & tullut (NUT) & 'the one who came' \\
\hline Patient-oriented & $s c e d w \bar{\imath}(\mathrm{WE})$ & ommeltu (TU) & '(the item that was) sewn' \\
\hline
\end{tabular}

Table 1: Orientation of the past participles in Tundra Nenets and in Finnish

The agent of the patient-oriented participle can also be overtly expressed with a possessive suffix equivalent to the person of the agent and a genitive form of the agent noun. Consider examples 20 and 21 below, where the past participle forms jo-me 'lost [by someone]' and yawlampə-we-mi 'fed by me' take the possessive suffix according to the person of the agent, the first person singular in 20 and the third person singular, Nina, in 21.

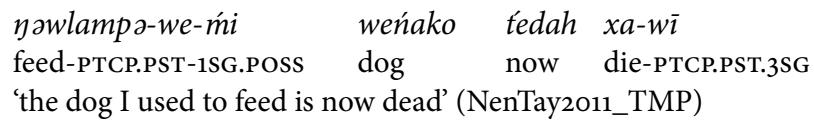
Nina-h jo-me-da
telefon-ta
tukū-na
Nina.GEN loose-PTCP.PST-3SG.Poss telephone-3SG.Poss this-Loc be.3SG
'The telephone that Nina lost is here.' (NenTay2011_TMP)

In predicate position, the past participle of a transitive verb is also patientoriented. This can be seen by contrasting examples 22 with past participle predicate and 23 with narrative mood (= examples 2 and 3 in section 1 ).

(22) yopoj śanaku toxoća-xad soed-wī

one toy patch-ABL sew-PTCP.PST.3SG

'one toy is sewn of patches' (one toy (is) of-patch sewed) (NW: 19.7.2008)

$\begin{array}{lll}\text { (23) jile-wa-n-ta } & \text { jampa-nh mala } & \text { yoka } \\ \text { live-NMLZ-GEN-3SG.POSS long-LAT already many } & \text { lod }\end{array}$

pani-m? soed-wi

clothing-ACC SeW-NARR.3SG

'During her lifetime she has sewn many clothes.' (NW: 20.3.2008) 
In both examples, the form of the transitive verb looks the same, scedwi 'sewn', but the examples differ in their orientation. In example 22, the subject śanaku 'toy' is not the agent but the patient or the action expressed by the predicate, whereas in 23 , the third person subject is the agent, the active performer of the action, and the patient, the direct object 'many clothes', is marked with the accusative. The same difference between the patientoriented participial predicate and the active narrative mood is illustrated in examples 24 and 25.

(24) tuku xar xurka jeśa-xəd śerta-wī?

that knife which metal-ABL make-PTCP.PST.3SG

'What kind of metal is that knife made of?' (T65: 111)

(25) tiki śer-m ${ }^{2}$ jisawejh śerta-we-da
this thing-ACC smartly make-NARR.sG<3SG
'He has done this smartly' (T65: 150)

The agent of the patient-oriented past participle can also be added to a passive construction. Nikolaeva (2014: 239-245) gives several examples of passive clauses with syntactically expressed agents. However, in text collections and the data of this study, the overt expression of the agent in the passive construction is rare, and most of the patient-oriented past participle predicates are agentless, as in examples 24 and 25 above. The agent of the passive construction can be marked either with genitive (26) or with locative (27), and in cases with a first or second person agent, the participial takes the possessive suffix according to the person of the agent:

tiki xən melad-h śerta-wī
this sledge master-GEN make-PTCP.PST.3SG
'This sledge was made by a master.' (T65: 247)
mań weńako-xana śakal-me-da
yoe-we-dm?
I dog-LOC bite-PTCP.PST-3SG.POSS be-NARR-1SG
'I was bitten by a dog.' (NenTay2011_TMP)

An agent in genitive, as in 26, corresponds with the strategy that is used when the participle is in modifying position, as in 21 earlier. The locative agent appears in translations and elicited data, possibly due to Russian influence. In Russian, the instrumental case is used to encode the agent in passive constructions, and in Tundra Nenets, the locative case 
is also used to express instrumental function. According to Nikolaeva (2014: 241), the locative agent is used in the western varieties, but it also occurs in my field data deriving from the Eastern area, however only in elicited sentences.

\section{The resultative predicate -we}

In predicate position, the Tundra Nenets past participle encodes a state or quality that derives from a past action or event, as in the previous examples 24 'is made of metal' and 22 'is sewn of patches', and it can be considered a resultative. Nedjalkov \& Jaxontov (1988: 6) define resultatives as constructions that signal that a state exists as a result of a past action. Making the patient the subject, as in the same patient-oriented examples from Tundra Nenets, is also a characteristic of resultatives in different languages (Bybee et al. 1994: 54).

In predicate position, participles behave syntactically like nominal predicates. In indicative affirmative clauses, non-verbal predicates are formed by adding the verbal suffixes of the subjective (intransitive) conjugation directly onto the nominal stem, and in the case of participial predicates, after the participial suffix. Participial predicates cannot agree with the subject using suffixes of the objective or the reflexive conjugation, and only suffixes of the subjective conjugation are acceptable. Furthermore, in negation, past participial predicates, like any other nominal predicates, use the copula verb ya 'be', to which the connegative marker is suffixed, see 28 .

\begin{tabular}{|c|c|c|c|}
\hline $\begin{array}{l}\text { yobtiki } \\
\text { also.there }\end{array}$ & $\begin{array}{cc}\text { jewaku } & \text { dolgan } \\
\text { orphan } & \text { dolgan }\end{array}$ & $\begin{array}{l}\text { jilée, } \\
\text { live.3SG }\end{array}$ & \\
\hline śa-ta & $p a d-w \bar{\imath}$ & $n^{\prime} \bar{\imath}$ & $y a^{-2}$ \\
\hline face-3sG.PC & SS draw-PTCP.PST & NEG.3SG & be-CNG \\
\hline
\end{tabular}

In the case of verbal predication, the connegative marker is affixed to the predicate verb, and the copula is not used:

$\begin{array}{lllll}\text { Narka Taśińij } & n i-w & \text { mane-s? } & \text { ńi-wi } & \text { tu-? } \\ \text { Older Tasinij } & \text { NEG-1SG>SG } & \text { see-CNG } & \text { NEG-NARR.3SG } & \text { come-CNG } \\ \text { 'Old Tasinij, I cannot see him; apparently, he did not come.' (JamLa: 59) }\end{array}$


In addition to negation, the copula is also used in the expression of nonindicative moods in past participle predicates just like in any nominal predicates, and the mood markers cannot be affixed to the participial stem. Examples 30 and 31 represent different inferential moods with a past participle predicate.

$$
\begin{array}{lll}
\text { yaxa na } & \text { to-wi } & \text { yo-wanykabá } \\
\text { long.time.ago } & \text { come-PTCP.PST } & \text { be-PROBII.3SG }
\end{array}
$$

'He has probably come a long time ago.'(T65: 390)

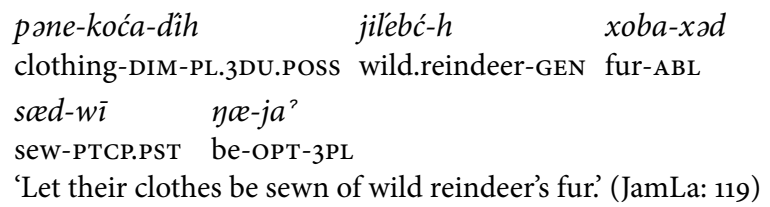

The copular strategy is also applied for past participle predicates with narrative mood marking. In this case, the predicate construction consists of a past participle and a copula suffixed with the narrative mood marker. The proposed resultative state is indicated with the past participle of the main verb, while the narrative mood in the copula adds the evidential meaning. Consider examples 32-33:

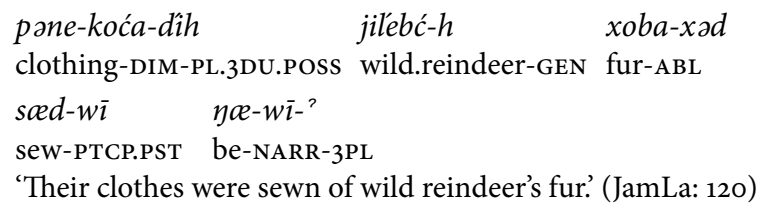

$$
\begin{array}{lll}
t i & x a-w \bar{l} & y c e-w \bar{\imath} \\
\text { reindeer } & \text { die-PTCP.PST } & \text { be-NARR.3SG } \\
\text { 'The reindeer turned out to be dead.' (NenTay2011_LNF) }
\end{array}
$$

The examples of negation in 28 vs. 29 and non-indicative mood marking in 30-33 indicate that regardless of the homonymy of the two suffixes, the syntactic structure of the past participle and the narrative is different. Moreover, with transitive verbs, the two forms have different orientations with respect to the subject of the clause (narrative mood in agent-oriented or active expression, past participle in patient-oriented or passive expression), as was demonstrated in section 3 (examples 22-25). Furthermore, as a nominal predicate, the past participle cannot agree with the subject using the personal suffixes of the objective or reflexive conjugation. 
However, with certain verbs, the syntactic structure of the two forms is also the same. The constructions look similar in indicative affirmative clauses with those intransitive verbs that denote a change of state. In these kinds of clauses (34 and 35), without a wider context, both interpretations, the narrative mood and the resultative past participle, would be possible.

(34) $t i \quad x a-w \bar{\imath}$

reindeer die-PTCP.PF.3SG/-NARR.3SG

'The reindeer is dead/has died.' (NenTay2011_LNF/TMP)

(35)
ńe-h
panī-da
womtara-wi- ${ }^{2}$
woman-GEN clothing.PL-3SG.POss become.ragged-PTCP.PF-3PL/-NARR-3PL
'The woman's clothing is/has become ragged.' (T65:56)

Both examples 34 and 35 denote a past event that affects the subject and changes its state. However, the clauses can both refer to either the past event ('The reindeer has died'), or the state resulting from the event ('The reindeer is dead'). Bybee et al. (1994: 63) demonstrate the difference between these functions, the past event with current relevance (perfect) and state resulting from a past event (resultative), with the following examples from English:

He is gone.

He has gone.

The door is closed. ${ }^{9}$

The door has closed. (Bybee et al. 1994: 63).

In English, the constructions with be are resultative, whereas the constructions with have represent the perfect. In Tundra Nenets, the difference is clear when it comes to transitive verbs, because the subject of the resultative past participle formed from a transitive verb is its patient, and the subject of the narrative mood is its agent. Therefore, the resultative state in example 22 in section 3 ('the toy is sewn of patches') follows from a past action similar to what is illustrated in example 23 in the same section ('she has sewn many clothes').

Time adverbials can be used as test for distinguishing perfects and related categories, as only resultatives, but not perfects, can combine with time adverbs expressing unlimited duration (Nedjalkov \& Jaxontov 1988: 15-16; Lindstedt 2000: 370). In Tundra Nenets, the time adverbial tedah 'now' as in example 37 ( $=20$ in section 3$)$ appears with the perfect participle predicates that encode state. Thus, in this context, the predicate $x a w \bar{\imath}$ 'dead' can more naturally be interpreted as resultative encoding state than as a narrative that would refer to the past event. 
In my data, there are no certain examples of imperfective/continuative verbs such as 'live' in past participle predicates: the are no examples of nominal negation, modal marking with copula, appearance with time adverbials of unlimited duration, etc. Consequently, the -we forms of these verbs in predicate position are analysed as examples of the narrative mood. Consider the verb 'live' in example 38 :

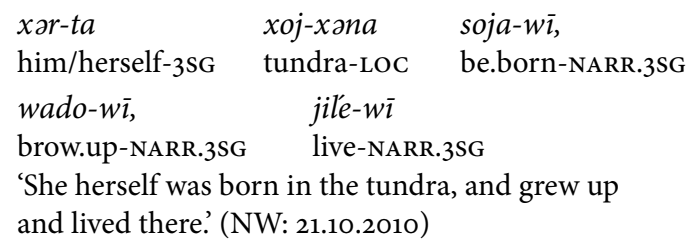

Thus, only the past participles formed from verbs that have perfective lexical aspect, such verbs as 'make', 'sew' and 'die' in the previous examples 22, 24 and 33, can act as predicates. However, the past participle forms of imperfective verbs such as 'run' and 'live' appear in modifying position, usually specified by an adverbial that expresses time or location:

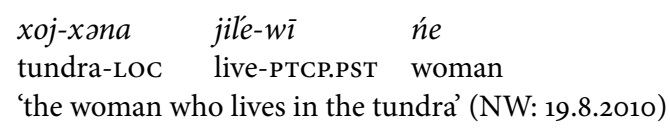

In Tundra Nenets, it is possible to form past participle predicates from perfective verbs expressing telic events that are complete at least in some sense. These events have affected their participants and caused the state that characterizes the participant as a result of the event. Haspelmath (1994: 157-161) argues that resultative participles from intransitive verbs are usually possible only if the situation is telic (Nedjalkov \& Jaxontov (1988: 5) use the concept terminative). This follows from the fact that atelic events are not considered to result in any state (Haspelmath 1994: 160). In this sense, the Tundra Nenets past participle can be defined as a prototypical resultative participle only in predicate position. However, past participles from imperfective verbs, such as 'lived' in 38 , are also used to characterize the head noun with a past completed event or experience that has probably affected the subject. 
In addition to the telicity condition, another feature typical of resultative participles their orientation towards a non-agentive participant. Haspelmath (1994: 157-159) gives examples of different languages, where passive past participles are formed from transitive verbs and active participles are formed from telic intransitive verbs or unaccusative verbs, whose argument is not the agent but resembles more the patient of a transitive verb. Following Nedjalkov's and Jaxontov's (1988: 6) definition of resultatives, Haspelmath (1994: 159-161) suggests the notion resultative participle for these morphemes that create past passive participles from transitive verbs (abused child) and past active participles from telic intransitive or unaccusative verbs (wilted dandelion).

In Tundra Nenets, too, the majority of past participle predicates are typically oriented towards their patient or experiencer. Past participles from transitive verbs are patient-oriented (passive), and many of the past participles from intransitive verbs are formed from unacussative verbs such as 'become ragged', 'die' or 'be born', as in the previous examples 38, 33, 34 and 36 . The common property of these verbs is that their only participant is not the agent but rather resembles the patient that is affected by the action expressed by the verb. For this reason, participles from unaccusative verbs can be considered patient-oriented, even if they are not passive. Table 2 summarizes the appearance and semantic orientation of the past participles from different types of verbs in Tundra Nenets: past participles from transitive verbs and unaccusative intransitive verbs are patient-oriented, while past participles from agentive (unergative) intransitive verbs are agent-oriented.

\begin{tabular}{|l|l|l|}
\cline { 2 - 3 } \multicolumn{1}{c|}{} & $\begin{array}{l}\text { Participial } \\
\text { modifier in NP }\end{array}$ & $\begin{array}{l}\text { Participial } \\
\text { predicate }\end{array}$ \\
\hline Transitive verb & P ('sewn') & P \\
\hline Intransitive unaccusative verb & P ('was born') & P \\
\hline Intransitive agentive perfective verb & A ('came') & A \\
\hline Intransitive agentive imperfective verb & A ('lived') & no examples \\
\hline
\end{tabular}

$\mathrm{P}=$ participant equivalent to patient, $\mathrm{A}=$ agent participant

Table 2: Orientation of the past participles from different types of verbs in Tundra Nenets 
In the data, there are no examples of past participles from intransitive imperfective verbs, which can be explained by the telicity condition of the resultatives. Furthermore, it can be concluded that it is the patient-oriented past participle predicates in Tundra Nenets appear in (agentless) passive and anticausative (unaccusative) constructions. Both of these constructions express a state resulting from an event that has affected the state of the subject. Moreover, agent-oriented past participles can be formed from intransitive agentive verbs, which in modifying position tend to appear in a context that limits the range of the process. In predicate position, it appears that only past participles of perfective verbs can be used as resultative predicates.

\section{The derivational resultative $-b e j$}

In the context of the resultative participle -we, another resultative suffix, -bej ( -pej), must also be mentioned. In the western and middle dialects of Tundra Nenets, this deverbal suffix can also be used for expressing properties very similar to the resultative states expressed by the past participle (see Tereščenko 1956: 180-181; 1965: 910; Hajdú 1968: 51). Consider examples 40 and 41 with the word tirabej 'dry; thin; weak' from tira (ś) 'to wither; to dry':

(40) tira-bej xoba

dry-Res fur

'dried fur' (T65: 681)

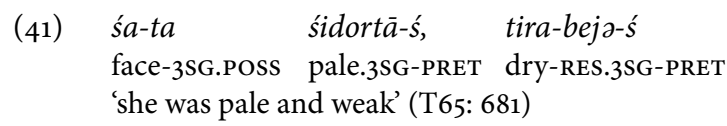

Despite the resultative, participle-like use of the suffix - $b e j$, it is not considered a participle but rather a deverbal adjectival derivative suffix. Despite the fact that participles are often characterized as verbal adjectives because of their syntactic position, they are not real adjectives in the sense that they would only denote a property; they instead to the action or event expressed by the verb. Consequently, in modifying position, the event they refer to can be specified using adverbials of time, place, manner or cause (43). As for - bej forms, they are not participial forms of verbs, but rather adjectives derived from verbs that express property, and they do not usually appear with adverbials of time and place or expression of manner or cause (42). 
The difference between -we participles and -bej suffixes can be illustrated by the following examples of Tereščenko (1956: 181).

(Tereščenko 1956: 181)

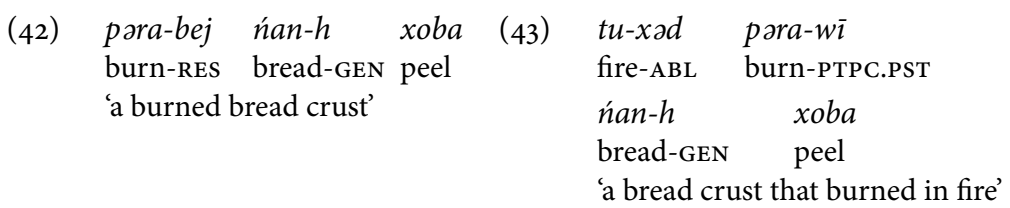

The dictionary (Tereščenko 1965) gives many of these forms in - bej as dialectal variants of the past participle forms of the same verb, or the other way around: śamtbej $\approx$ śamtwī 'smoked (transitive)', jurwī $\approx$ jurbej 'forgotten', prawi $\approx$ parabej 'burned'. The orientation of the -bej forms depends on the transitivity of the verb in the same way as with past participles, as can also be seen in examples $42-43$.

In the data, in the material deriving from the eastern dialectal area on Taimyr Peninsula (JamLa and NenTay2011), the suffix - bej appears only with a few forms, which may be lexicalized. It appears in certain deverbal derivations, the most common being xabej 'dead' (instead of xawi as in example (37) above):

(44) məńije-pnan-ta wari ma-ta
see-sub-3SG.Poss barely tent-PL3SG.POss
ter['] $\quad$ xa-bej $\quad$ Đe-rxa
resident[PL] die-REs be-sIMEv.3SG
'When he saw it, the residents of the tent seemed to be dead.' (JamLa: 26)

In addition to xabej 'dead', such deverbal adjectives as yarmpej 'aged', yajabej 'young', xinebej 'decent' also appear in the data from the Taimyr Peninsula. As for the data from the western dialect, the newspaper texts in $\mathrm{NW}$ include several examples of resultative adjectives in -bej derived from different verbs, in both modifying and predicative position:

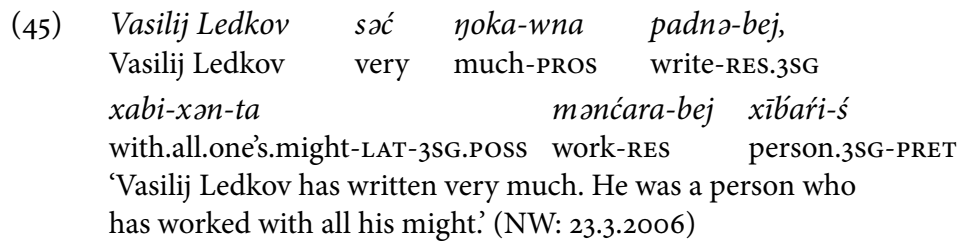




(46) 1942 po-xəna tipcrta- $[h] \quad$ semja-xəna soja-bej
1942 year-LOC reindeer.herder-GEN family-LOC be.born-RES.3SG
'He was born in 1942 into the reindeer herder's family.' (NW: 14.5.2005)

In the data from in the western varieties of Tundra Nenets (NW), the forms in -bej appear to be replacing past participles and also the narrative mood in many contexts (see also Nikolaeva 2014: 107-108). The newspaper texts in NW include several examples of predicates in -bej, some of them also in transitive clauses, as in $47(=14)$, where the predicate is agent-oriented and the object is overtly expressed. In other varieties of the language, the narrative mood would be used in this context (cf. 23 in section 3).
Pida yok
(s)he
yamke-m yerm-
$j a-h$
je əmńa
śerta-bej
'She has done a lot for the northern land.' (NW: 15.11.2005)
do-RES.3SG

It is noteworthy that although the syntax and semantics of the - bej forms in affirmative clauses resembles the narrative mood, in negation it uses the nominal strategy in the same way as participial predicates (48), and in the data, there are no examples of the verbal negation strategy applied to the predicate in $-b e j$.
ńeneć-je?
kultura- $m^{2}$ wada- $m^{2}$
namta-bej
ńi-? ${ }^{?} \quad y a-^{?}$
Nenets-GEN.PL culture-ACC language-ACC comprehend-RES NEG-3PL be-CNG 'They did not understand the Nenets culture and language.' (NW: 14.1.2010)

The negation strategy suggests that also in the western varieties of the language, the status of forms in -bej is nominal and syntactically closer to the past participle than the narrative mood. However, it seems that in the western varieties, in addition to the resultative predicate function, the form is also gaining functions of the narrative mood, and it might be in process of replacing it in these varieties. As was pointed out in section 2, the preterite form of the narrative mood is much more common in the data of NW than the plain narrative mood. This also indicates that the functions expressed by the narrative mood in other varieties are often replaced by other strategies in the western varieties. 


\section{Development of the resultative and perfect/evidential constructions}

The resultative past participle and the narrative mood in Tundra Nenets are identical, and also semantically close to each other. For this reason, it is plausible that they also have a common origin. The past participle predicate refers to a state that results from a past action, whereas the narrative mood expresses various evidential functions of a past event including functions closely connected to the definition of perfect. Resultative and perfect are, in a way, different perspectives on the same event or action (see also Dahl 1985; Aikhenvald 2004: 112). Traces or results of a past action or event are evidence for inferring that the past event has taken place. However, inference based on traces of a past event requires observation of the results as they appear in the current moment. Using the examples of Bybee et al. (1994: 63), the state He is gone results from the past action He has gone. Respectively, the past action He has gone can be inferred from the existing state He is gone.

\section{Past}

Action/event

He has gone

The door has closed

perfect (past action)

\author{
Current moment \\ results \\ He is gone. \\ The door is closed \\ resultatives (state resulting \\ from a past action)
}

Moreover, as well as evidentiality, also mirativity, which characterizes a proposition as newsworthy, unexpected, or surprising, may grammaticalize from resultative (Hengeveld \& Olbertz 2012: 498-500). This way, mirativity can be considered to include both discovering the resultative state and expressing unexpectedness or importance of the state or the event that it results from.

Although the suffixes of the past participle and the narrative mood are identical in Tundra Nenets, comparison to the closest related language shows that in an earlier stage of the language, they have probably been morphologically distinct. In Forest Nenets, the suffix for past participle is $-m \ddot{a}$ whereas for narrative mood, the suffix is -mâj (Salminen 2012: 342; see also Sammallahti 1974: 81-82, 93). The past participle suffix of the Nenets languages derives back to the past participle reconstructed to Proto Samoyedic as ${ }^{\star}-m \varnothing(-y \varnothing)$, which goes back to Proto-Uralic (Janhunen 
1998: 473). The narrative mood, perfect or similar finite verbal category has not been reconstructed to Proto-Samoyedic, and it appears to be of more recent origin. However, the close functions of the resultative past participle and the narrative mood in the contemporary languages as well as their similarity in form indicate that the origin of the two forms is common. Table 3 illustrates the development of the past participle and narrative suffixes in the Nenets languages.

\begin{tabular}{|l|l|l|}
\cline { 2 - 3 } \multicolumn{1}{c|}{} & Past participle (non-finite) & Narrative $\operatorname{mood}$ (finite) \\
\hline Proto Samoyedic & ${ }^{*}-m \emptyset-y \emptyset$ & - \\
\hline $\begin{array}{l}\text { (Pre-)Proto } \\
\text { Nenets }\end{array}$ & $\begin{array}{l}\text { Emergence of the finite predicate and } \\
\text { divergence of the two categories }\end{array}$ \\
\hline Forest Nenets & $-m \ddot{a}$ & $-m a \hat{j}$ \\
\hline Tundra Nenets & $-w e(\sim m \bar{\imath}=m i a)$ & $-w e(\sim m \bar{\imath}=m i a)$ \\
\hline
\end{tabular}

Table 3: Development of the past participle and narrative in the Nenets languages

If there were already two formally different suffixes in Proto-Nenets, the narrative mood would already have developed before this stage of the language, but probably after the Proto-Samoyedic period, as there are no finite cognates in the other Samoyedic languages. If the narrative mood developed from the past participle form, the resultative past participle form was then reanalysed as a finite predicate, the perfect, which later developed evidential meanings. The emergence of the differentiated suffixes can probably be explained by the different morpho(syn)tactic position of the non-finite form and the finite predicate. Later, in Tundra Nenets, the two suffixes merged, but in Forest Nenets they have remained differentiated.

The current situation in Tundra Nenets, where the two different functions are morphologically homonymous, reflects a similar situation assumed to have existed in an earlier stage of the language, called Pre-ProtoNenets in Table 3. Assuming that the resultative predicate encoded by the past participle has developed into the narrative mood, it must also be assumed that the two functions were first encoded by one suffix. A precondition for the emergence of a new form in this kind of situation is polysemy of the original form, which leads to its reanalysis as a new category (see Hopper 1991: 22; Hopper \& Traugott 2003: 124-126). This means that different functions and perhaps later also differentiated forms exist in the lan- 
guage side by side. From this perspective, analysing the two homonymous forms in Tundra Nenets gives information about the original situation in an earlier stage of the language before the two forms started to differentiate. Thus, Tundra Nenets can be used as an example language illustrating the reanalysis of the resultative construction as perfect and evidential in the history of the language.

It was demonstrated in the earlier sections that the non-finite (past participle) and finite (narrative) predicate in -we differ from each other in their basic semantics and orientation as well as in syntax in many contexts. In order to trace the construction in which the reanalysis of the original form would have been possible, we must examine the contexts where the two constructions are identical. Looking at the orientation of the past participles from different types of verbs and their appearance in predicate position (Table 4), we can conclude that participial and narrative predicates of intransitive unaccusative verbs and intransitive agentive verb of perfective aspect are those with a similar orientation.

\begin{tabular}{|l|l|l|l|}
\cline { 2 - 4 } \multicolumn{1}{c|}{} & $\begin{array}{l}\text { Participial } \\
\text { modifier in NP }\end{array}$ & $\begin{array}{l}\text { Participial } \\
\text { predicate }\end{array}$ & Finite predicate \\
\hline Transitive verb & $\mathrm{P}$ ('sewn') & $\mathrm{P}$ ('x is sewn') & $\mathrm{A}$ ('y sewed x') \\
\hline $\begin{array}{l}\text { Intransitive } \\
\text { unaccusative verb }\end{array}$ & $\mathrm{P}$ ('was born') & $\mathrm{P}$ & $\mathrm{P}$ \\
\hline $\begin{array}{l}\text { Intransitive agentive } \\
\text { perfective verb }\end{array}$ & $\mathrm{A}$ ('came') & $\mathrm{A}$ & $\mathrm{A}$ \\
\hline $\begin{array}{l}\text { Intransitive agentive } \\
\text { imperfective verb }\end{array}$ & $\mathrm{A}$ ('lived') & no examples & $\mathrm{A}$ \\
\hline
\end{tabular}

$\mathrm{P}=$ participant equivalent to patient, $\mathrm{A}=$ agent participant

Table 4: Orientation of the past participles from different types of verbs in Tundra Nenets

Because the orientation in the non-finite and finite predicate are the same, predicates of intransitive unaccusative verbs and intransitive agentive verbs of perfective aspect are the best candidates for the original polysemous construction that led to the reanalysis of the resultative construction. The reanalysis of these verbs expressing situations that change the state of a participant has produced the new perfect or evidential construction. Example 49 shows the polysemy of the Tundra Nenets constructions and illustrates the assumed reanalysis that took place in Pre-Proto-Nenets: 
(49) $t i$

$x a-w \bar{\imath}$

reindeer die-PTCP.PST.3SG $>$ die-NARR.3SG

'The reindeer is dead.' > 'The reindeer has (apparently/reportedly) died'

As was argued in section 4, examples 34 and 35 can be interpreted either as resultative (nominal predicate in past participle) or evidential (narrative mood). From the perspective of grammaticalization, the polysemy of the construction (is dead/has died) has opened up the possibility for reanalysis of the construction as a finite predicate and the resultative predicate suffix as a mood suffix. The reanalysis of the form as a mood suffix has made it possible to conjugate the form also in objective and reflexive conjugation and to apply verbal negation strategies.

A very similar development is currently taking place in the western varieties of Tundra Nenets, where the suffix -bej, which in other varieties is used as a deverbal adjectival suffix, is used as resultative participle suffix that also appears to have partially replaced the narrative mood as a finite perfect-like suffix. This suffix originates from a Proto-Samoyedic past participle ${ }^{*}-p V j u^{10}$ (Mikola 1988: 259), and some of its cognates in other Samoyedic languages are used as finite suffixes. Most importantly, in Forest Enets, the suffix - $b i$ - a cognate of the Tundra Nenets - $b e j$ (ibid.) is the perfect marker (Siegl 2013: 263-264) ${ }^{11}$. Originating from an earlier participial or verbal noun marker, the Forest Enets perfect is a result of the same grammaticalization process that its cognate suffix is undergoing in the western varieties of Tundra Nenets: $x a b e j$ 'dead' (resultative adjective) $\rightarrow$ xabej 'has died' (perfect). The -bej forms are considered non-finite forms and their negation is nominal (see 3.3., example 48), but they still have some properties of finite predicates (see 3.3., examples 46 and 47 ). This is why they can be considered an example of an ongoing grammaticalization process of a non-finite resultative into finite perfect construction, the parallel case for what has been suggested for the development of the Tundra Nenets narrative mood in this study, and probably also for the development of the Forest Enets perfect.

The development of resultatives into perfects and further into indirect evidentials or past tense markers is a tendency in many languages of Eurasia but also in languages spoken in other parts of the world (Comrie 2000: 3, 6; Bybee et al. 1994: 95). ${ }^{12}$ The notion of perfect appears to be a link between resultative state and indirect evidentiality illustrated by examples 
drawn from many languages. However, prefect is typically not the only function of a marker, and it is very common for perfects to develop further into past tenses or indirectives (Lindstedt 2000: 378). As was discussed in section 2, most languages spoken in the Central Eurasian area (SouthEastern Europe and Western Asia) have an indirect evidential category deriving via perfect interpretation from resultative constructions (Comrie 2000: 3; Lindstedt 2000; Lazard 2001: 360). Contact with Turkic languages is one plausible source of the development in all these languages (Johanson 2000: 83-84; Friedman 2000: 357; Aikhenvald 2004: 289), but the typological perspective and the structure of the languages must also be considered (Friedman 2000: 357).

What has not been emphasized in earlier studies of resultatives developing into perfects and indirectives is that the change from resultative into perfect/indirective often involves a change in predicate type from non-verbal to verbal. In many languages, perfects develop from past participial forms of the main verb appearing with or without a 'be' auxiliary ${ }^{13}$ (Bybee et al. 1994: 95-96). However, what is noteworthy about indirectives and perfects from the perspective of many languages of the Central Eurasian area is that in the same languages where perfects and indirectives develop from resultatives at the functional level, their origin at the syntactic level is in non-finite past participle constructions. For example, the East Old Turkic $-m i s ̌(>$ e.g. Turkish $-m I s ̧$ ) was used both as a finite and non-finite unit (Johanson 2000: 62), and the two different uses of the morphologically identical forms, resultative in non-finite constructions and evidential in finite constructions, remain in contemporary Turkish (Csató 2000: 33). In Balkan Slavic languages, the evidential form also derives from a common Slavic resultative participle (Friedman 1986: 171). Moreover, in Ob-Ugric and Permic languages, as well as Northern Tungusic languages, evidential markers are similar to participles and originate from them (Johanson 2000: 62; Nikolaeva 1999; Leinonen 2000: 421-422; Malchukov 2000: 457). It appears that in languages that use copula-less non-finite predication for participles, like Tundra Nenets, the evolution of resultatives into evidentials or perfects is directly linked to nonverbal predicates becoming part of verbal predication strategies.

Looking from an areal-typological perspective, it is evident that resultatives are a common source for perfects and indirect evidentials in many languages, especially in the area of Central Eurasia. The clear semantic similarity of the functions of resultative and perfect is an obvious precon- 
dition for this development. Another factor seems to be the expressing of resultativity with past participial predicates, which seems to be the strategy used by most of the languages of the area. Thus, instead of grammatical replication as result of direct language contact, the grammaticalization of the narrative mood in Nenets might be an expected consequence of the syntactic structure used for certain functions, namely expressing resultativity with past participle predicates. The potential of resultatives to develop into perfects is actualized when the syntactic structure allows for a reanalysis of the original construction. This is also what is happening with the $-b e j$ forms in the western varieties of contemporary Tundra Nenets. However, even if direct language contact would not be the only plausible source of these grammaticalization processes in Nenets, the earlier contacts of Proto-Samoyedic with Turkic and also later contacts with other Siberian languages cannot be ignored, considering the structural similarities of the languages where the development of resultative participles into perfects and evidentials has taken place.

\section{Conclusion}

Languages acquire evidentials through contact, borrowing categories rather than forms (Aikhenvald 2004: 302), and the development of resultatives into perfects and indirective evidentials is a well-known tendency attested in many languages. This tendency has also been regarded as an areal phenomenon in an area covering the usage areas of Turkic and its neighbouring languages (Dahl 1985: 152; Johanson \& Utas 2000; Lazard 2001: 360). In the context of Eurasian languages, the evolution of resultative predicates in Nenets seems to follow the same development paths attested in many other languages.

In this study, I have analysed two identical suffixes in Tundra Nenets, the past participle (-we) and the narrative mood (-we) from both a synchronic and a diachronic perspective. Synchronically, the forms have different main functions, as the past participle denotes resultativity, while the narrative mood is used to express different evidential functions, most importantly, an indirect source of information or some sort of distance between the speaker and the proposition. However, both forms refer to the past: past participles denote the resultative state of a past event, while the narrative mood encodes information about a past event. In predicate position, the past participle is a non-finite predicate, whereas the narrative 
mood is finite. Consequently, they use different strategies in certain syntactic positions, for example in negation. Furthermore, the past participles from transitive verbs are patient-oriented or passive in that their subject is the patient, whereas the predicate in narrative mood agrees with its subject, which is the agent.

I have argued that the narrative mood -we has developed from the past participle through reanalysis of the resultative predicate as perfect/evidential. This development most probably took place by the Proto-Nenets period, as in addition to Tundra Nenets, the narrative mood appears in its closest related language, Forest Nenets. Forest Nenets material indicates that in Proto-Nenets, the past participle and the narrative mood suffix were differentiated in form, meaning that their homonymy in Tundra Nenets is result of a later merger. A development of a resultative suffix into a perfect-like finite suffix is currently going on in the western varieties of Tundra Nenets, where the deverbal adjectival suffix - bej, used in predicate position, has features of both nominal and verbal predication, and therefore seems to be grammaticalizing from a resultative marker into a marker of perfect tense.

The data from Nenets provides additional evidence of the tendency of resultatives grammaticalize into perfect markers and evidentials of indirectivity. The path of development and the functions of the narrative mood have parallels in many other languages of Central Eurasia, as well as in languages spoken relatively close to Nenets and other Samoyedic languages. The evidence from Nenets can be seen as expanding the borders of the area of Central Eurasian evidentials derived from resultatives. Furthermore, the evidence can be interpreted from the perspective of participial predicates as a precondition for the grammaticalization of resultatives into evidentials. The semantic potential of resultatives to develop into perfects is actualized in a certain syntactic construction, the predication of past participials.

Lotta Jalava

General Linguistics P.O. Box 24 (Unioninkatu 40) 00014 University of Helsinki <lotta.jalava@helsinki.fi> 


\section{Lotta Jalava}

\section{Notes}

1. Alternation $-w e \sim-w \bar{\imath}(-w i z)$ affixed to vowel stems, $-m e \sim-m \bar{\imath}(-m i a)$ affixed to consonant stems.

2. In his analysis of the form in Tundra Nenets, Salminen (1997: 98) follows Sammallahti's (1974: 82).

3. The fieldwork was conducted together with Florian Siegl. Some of the recordings were made by the author of this paper, some of them together with Siegl.

4. In these modifications I apply the principles of the (morpho)phonology of Tundra Nenets (see Salminen 1997). However, the transcription used here does not correspond with the phonological transcription used by Salminen, and it not aim to show the deep phonemic form of the words. For example, the special schwa phoneme marked with $/ \%$ by Salminen (1997) is not marked here in the contexts where it is not pronounced. Furthermore, the characters I use differ from the characters used in Salminen's transcription (1997) in many respects. For example, I use the apostrophe for palatal consonants (e.g. [ń]) instead of [Cy] (e.g. [ny]) used by Salminen, and the glottal stop is here marked with [ $\left.{ }^{2}\right]$ instead of [q] (as also in Wagner-Nagy 2011 and Siegl 2013).

5. Altogether approximately 10 ooo sample sentences.

6. Approximately 1300 clauses in preterite tense of the narrative mood, approx. 6000 clauses in the general past tense (the preterite tense of indicative), and approx. 600 clauses in narrative mood with no preterite marking in NW (consisting of roughly 30 ooo clauses).

7. In some other languages, mirativity can also be considered as an independent category that characterizes a proposition as newsworthy, unexpected, or surprising (Hengeveld \& Olbertz 2012: 490-498). Among those languages that express unexpected information with the same strategies which they use for expressing reported or inferred information are for example Turkish (the mIş-past) and the Balkan Slavic languages (the $l$-past) (Slobin \& Aksu 1982: 197-198; Friedman 2003; Lazard 2001: 361-363).

8. According to Ljublinskaja \& Malčukov (2007: 456-459), the main functions of the Nenets narrative mood ("perfect") are resultative (stative perfect), actional perfect, evidential perfect and admirative.

9. Often regarded as the "stative passive" in English (Bybee et al. 1994: 63).

10. According to Janhunen (1998: 473) a proto-Samoyedic verbal noun ${ }^{\star}$-mpa-yə that derives back to Proto-Uralic.

11. The Nganasan cognate suffix -HU ( -bi, etc.) is used as marker of past tense questions (Wagner-Nagy 2002: 113).

12. A number of well-studied examples are known from languages spoken in Eurasia such as Turkish and related languages (Aksu-Koç \& Slobin 1986: 165), as well as Bulgarian, Armenian, Macedonian and Georgian (Dahl 1985: 152), Germanic and Romance languages (Bybee et al. 1994: 68), and Eastern Uralic languages (Nikolaeva 1999; Leinonen 2000: 421-422).

13. In addition to past participle constructions, perfects may develop from possessive constructions (as in Germanic languages), from constructions with the main verbs and a particle meaning 'already', or from constructions with verbs such as 'finish' or 'cast aside' (Bybee \& Dahl 1989: 67-68). 


\section{List of abbreviations}

\begin{tabular}{|c|c|c|c|}
\hline \multirow[t]{2}{*}{ 1SG, etc. } & person and number of & MODER & moderative suffix \\
\hline & subject or possessor & NARR & narrative mood \\
\hline \multirow[t]{4}{*}{$1 \mathrm{SG}>\mathrm{SG}$, etc. } & person and number of & NEG & negative auxiliary \\
\hline & subject and number & NMLZ & nominalization \\
\hline & of object in objective & OPT & optative mood \\
\hline & conjugation & Poss & possessive \\
\hline $\mathrm{ABL}$ & ablative & PRET & preterite (past tense) \\
\hline ACC & accusative & PROB & probabilitative \\
\hline AUG & augmentative suffix & PROBII & probabilitative II \\
\hline CNG & connegative & PROS & prosecutive \\
\hline $\mathrm{CNV}$ & converb & PST & past \\
\hline COMIT & comitative suffix & РTCP & participle \\
\hline DIM & diminutive suffix & PURP & purposive converb \\
\hline EXCLAM & interjection & REFL & reflexive conjugation \\
\hline FUT & future (derivative tense) & RES & resultative adjective suffix \\
\hline GEN & genitive & SIMEV & similative-evidential \\
\hline LAT & lative & SUB & conditional converb \\
\hline LOC & locative & & (subordinative) \\
\hline
\end{tabular}

\section{Data}

JamLa = LabANAUSKaS 2001 (ed.) = К. И. Лабанаускас: Ямидхы " лаханаку” - Сказы седой старинь. Москва: Русская литература.

NenTay2011 $=$ Field recordings collected on the Taimyr Peninsula in autumn 2011 by Lotta Jalava and Florian Siegl.

NW = the column Ялумд" from the years 2005-2012 that appears in Няръяна вындер, the local newspaper of the Nenets Autonomous Okrug.

T65 = TerešČEnKO 1965 = Н. М. Терещенко 1965: Ненецко-русский словарь. Москва:

Советская Энциклопедия.

\section{References}

Aikhenvald, Alexandra Y. 2004: Evidentiality. Oxford: Oxford University Press.

Aksu-Koç, Ayhan A. \& Dan I. Slobin 1986: A Psychological Account of the Development and Use of Evidentials in Turkish. - Wallace Chafe \& Johanna Nichols (eds): Evidentiality: the Linguistic Coding of Epistemology. Norwood, New Jersey: Ablex. 159-167.

Bybee, JoAn L. \& Östen DAhL 1989: The creation of tense and aspect systems in the languages of the world. - Studies in Language 13: 51-103.

Bybee, Joan, Revere Perkins \& William Pagliuca 1994: The evolution of grammar: tense, aspect, and modality in the languages of the world. Chicago: University of Chicago Press. 
Castrén, Matthias Alexander 1845: Samoiedica 2-5: Jurak-Samoiedica 1-4. Manuscripta Castreniana. [Microfilm copy of the manuscript, National Library of Finland.]

COLLINDER, BJÖRN 1957: Survey of the Uralic languages. 2nd edition (1969). Stockholm: Almqvist \& Wiksell.

Comrie, Bernard 200o: Evidentials: semantics and history. - Lars Johanson \& Bo Utas (eds): Evidentials: Turkic, Iranian and Neighbouring Languages. Empirical Approaches to Language Typology 24. Berlin: Mouton de Gruyter. 1-13.

CsATó, Éva ÁGNES 200o: Turkish MIŞ- and IMIş-items: Dimensions of a functional analysis. - Lars Johanson \& Bo Utas (eds): Evidentials: Turkic, Iranian and Neighbouring Languages. Empirical Approaches to Language Typology 24. Berlin: Mouton de Gruyter. 29-43.

DAHL, Östen 1985: Tense and aspect systems. Oxford: Blackwell.

Dahl, Östen \& Viveka Velupillai 2013: The Perfect. - Matthew S. Dryer \& Martin Haspelmath (eds): The World Atlas of Language Structures Online. Leipzig: Max Planck Institute for Evolutionary Anthropology.

(Available online at $<$ http://wals.info/chapter/68>. Accessed on 2014-01-08.)

Décsy Gyula 1966: Yurak Chrestomathy. Indiana University Publications, Uralic and Altaic Series 50. Bloomington \& The Hague: Mouton.

DeLAnCEY, SCOTT 1997: Mirativity: The Grammatical Marking of Unexpected Information. - Linguistic Typology 1: 33-52.

Friedman, Victor A. 1986: Evidentiality in the Balkans. Bulgarian, Macedonian and Albanian. - Wallace Chafe \& Johanna Nichols (eds): Evidentiality: the Linguistic Coding of Epistemology. Norwood, New Jersey: Ablex. 168-187.

- 2000: Confirmative/Nonconfirmative in Balkan Slavic, Balkan Romance, and Albanian, with Additional Observations on Turkish, Romani, Georgian, and Lak. - Lars Johanson \& Bo Utas (eds): Evidentials: Turkic, Iranian and Neighbouring Languages. Empirical Approaches to Language Typology 24. Berlin: Mouton de Gruyter. 329366.

- 2003: Evidentiality in the Balkans with special attention to Macedonian and Albanian. - A. Y. Aikhenvald \& R. M. W. Dixon (eds): Studies in Evidentiality. Typological Studies in Language 54. Amsterdam - Philadelphia: John Benjamins. 189-218.

Hajdú, PÉTER 1968: Chrestomathia Samoiedica. Budapest: Tankönyvkiadó.

Haspelmath, Martin 1994: Passive participles across languages. - Barbara Fox \& Paul J. Hopper (eds): Voice: Form and Function. Typological Studies in Language 27. Amsterdam: Benjamins. 151-177.

Hengeveld, Kees \& Hella Olbertz 2012: Didn't you know? Mirativity does exist! Linguistic Typology 16 (3): 487-503.

Hill, Nathan W. 2012: "Mirativity" does not exist: hdug in "Lhasa" Tibetan and other suspects. - Linguistic Typology 16 (3): 389-433.

Hopper, PAUl J. 1991: On some principles of grammaticization. - Elizabeth Closs Traugott \& Bernd Heine (eds): Approaches to Grammaticalization, Vol. I. Amsterdam: John Benjamins. 17-36.

Hopper, Paul J. \& Elizabeth Traugott 2003: Grammaticalization. Cambridge: Cambridge University Press. 
Jalava, LotTA 2012: Tempuksen ilmaiseminen tundranenetsin moduksissa. - Tiina Hyytiäinen, Lotta Jalava, Janne Saarikivi \& Erika Sandman (eds): Per Urales ad Orientem. Iter Polyphonicum Multilingue. Festskrift tillägnad Juha Janhunen på hans sextioårsdag den 12 februari 2012. Mémoires de la Société Finno-Ougrienne 264. Helsinki: Société Finno-Ougrienne. 131-144.

Janhunen, Juha 1998: Samoyedic. - Daniel Abondolo (ed.): The Uralic Languages. London - New York: Routledge. 457-479.

Johanson, LARS 2000: Turkic indirectives. - Lars Johanson \& Bo Utas (eds): Evidentials: Turkic, Iranian and Neighbouring Languages. Empirical Approaches to Language Typology 24. Berlin: Mouton de Gruyter. 61-87.

Koptjevskaja-Tamm, Maria 1993: Nominalizations. London: Routledge.

Kuprijanova \& Barmič \& Номіс̌ $=3$. Н. Куприянова, М. Я. Бармич \& Л. В. Хомич 1985: Ненеикий язык. Учебное пособие для педагогических училищ. 4-е издание, переработанное. Ленинград: Просвещение.

Kuznecova \& Usenkova $2006=$ Н. Г. Кузнецова \& Э. В. Усенкова: Инферентиал в ненецком языке. - Linguistica uralica XLII: 276-296.

LABANAUSKAS 1974 = Казыс Лабанаускас: Ненецкий перфект. - Советское финноугроведение 10: 45-52.

- 1981 = Казыс Лабанаускас: Предположительное наклонение в ненецком языке. - Советское финно-угроведение 17: 49-61.

- 1982 = Казыс Лабанаускас: Наклонение кажущегося действия в ненецком языке. - Советское финно-угроведение 18: 283-292.

LAZARD, GILBERT 1999: Mirativity, evidentiality, mediativity, or other? - Linguistic Typology 3: 91-109.

- 2001: On the Grammaticalization of evidentiality. - Journal of Pragmatics 33: 359367 .

LeINONEN, MARJa 2000: Evidentiality in Komi Zyryan. - Lars Johanson \& Bo Utas (eds): Evidentials: Turkic, Iranian and Neighbouring Languages. Empirical Approaches to Language Typology 24. Berlin: Mouton de Gruyter. 419-40.

LINDSTEDT, JouKo 2000: The perfect - aspectual, temporal and evidential. - Östen Dahl (ed.): Tense and aspect in the languages of Europe. Empirical Approaches to Language Typology, no. 20-6. Berlin - New York: Mouton de Gruyter. 365-383.

Ljublinskaja \& MaL'ČUKov $2007=$ М. Д. Люблинская \& А. Л. Мальчуков: Эвиденциальность в ненецком языке. - В. С. Храковский (Ред.): Эвиденциальность в языках Европы и Азии. Сборник статей памяти Наталии Андреевны Козиниевой. Санкт-Петербург: Наука.

Malchukov, Andrej L. 200o: Perfect, evidentiality and related categories in Tungusic languages. - Lars Johanson \& Bo Utas (eds): Evidentials: Turkic, Iranian and Neighbouring Languages. Empirical Approaches to Language Typology 24. Berlin: Mouton de Gruyter. 441-470.

Miкоla, Tiвor 1988: Geschichte der samojedischen Sprachen. - Denis Sinor (ed.): The Uralic languages: description, history and foreign influences. Handbuch der Orientalistik 8: Handbook of Uralic studies 1. Leiden: E. J. Brill. 219-263.

Nedjalkov, Vladimir P. \& Sergej Je. Jaxontov 1988: The typology of Resultative Constructions. - V. Nedjalkov (ed.): Typology of resultative constructions. Typological studies in Language 12. 3-62. [Original in Russian 1983: Leningrad: Nauka.] 
Nikolaeva, Irina 1999: The semantics of Northern Khanty Evidentials. - Journal de la Société Finno-Ougrienne 88: 131-59.

- 2014: A grammar of Tundra Nenets. Mouton Grammar Library 65. Berlin: Mouton de Gruyter.

Perrot, Jean 1996: Un Médiatif Ouralien: Lauditif en Samoyède Nenets. - Zlatka Guentchéva (ed.): L’Énonciation Médiatisée. Louvain - Paris: Peeters. 157-68.

Salminen, Tapani 1997: Tundra Nenets inflection. Memoires de la Société Finno-Ougrienne 227. Helsinki: Suomalais-Ugrilainen Seura.

- 1998: Nenets. - Daniel Abondolo (ed.): The Uralic languages. London: Routledge. 516-547.

- 2012: Traces of Proto-Samoyed vowel contrasts in Nenets. - Tiina Hyytiäinen, Lotta Jalava, Janne Saarikivi \& Erika Sandman (eds): Per Urales ad Orientem. Iter Polyphonicum Multilingue. Festskrift tillägnad Juha Janhunen på hans sextioårsdag den 12 februari 2012. Mémoires de la Société Finno-Ougrienne 264. Helsinki: Société Finno-Ougrienne. 339-358.

Sammallahti, Pekka 1974: Material from Forest Nenets. Castrenianumin toimitteita 2. Helsinki: Suomalais-Ugrilainen Seura.

Siegl FlORIAN 2013: Materials on Forest Enets, an Indigenous Language of Northern Siberia. Memoires de la Société Finno-Ougrienne 267. Helsinki: Suomalais-Ugrilainen Seura.

Slobin, Dan I. \& Ayhan A. Aksu 1982: Tense, Aspect and Modality in the Use of the Turkish Evidential. - Paul J. Hopper (ed.): Tense-Aspect: Between semantics \& pragmatics. Typological Studies in Language, 1. Amsterdam \& Philadelphia: John Benjamins. 185-200.

TEREščENKO 1947 = H. М. Терещенко: Очерк грамматики ненецкого (юрако-самоедского) языка. Ленинград: Учпедгиз.

- 1956 = Н. М. Терещенко: Материалы и исследования по языку ненцев. Москва \& Ленинград: Издательство Академии Наук СССР.

- $1965=$ Н. М. Терещенко 1965: Ненецко-русский словарь. Москва: Советская Энциклопедия.

- 1973 = Н. М. Терещенко: Синтаксис самодийских языков. Ленинград: Наука.

WAgner-NagY, Beáta 2002: Chrestomathia nganasanica. Szeged: SZTE Finnugor Tanszék. 